\title{
Terminology
}

\section{AN EXTENSION OF THE NOMENCLATURE FOR IMMUNOGLOBULINS *}

Earlier proposals for the nomenclature of human immunoglobulins ${ }^{1}$ have been generally accepted. Recent studies of the remarkable heterogeneity of immunoglobulins and of antibodies have produced additional findings on human immunoglobulins which require the extension of the existing terminology. Certain new terms are therefore proposed for well-established properties of the structure and amino acid sequences of the heavy and light chains of these proteins. These additions to the terminology should help in defining those regions of antibody molecules which are responsible for their two major kinds of functions-i.e., the function of antigen binding and those other functions which are manifested by biological properties such as complement fixation.

\section{Definition of the regions of immunoglobulin molecules}

It is now clear that the polypeptide chains of immunoglobulins consist of 2 well-defined regions which are here designated "the variable region" and "the constant region". The variable region has been so designated because of the diversity of its amino acid sequences, whereas the constant region is relatively invariable in molecules of the same class and type. It is recommended that the variable and constant regions be termed the " $\mathrm{V}$ region" and the " $\mathrm{C}$ region" respectively. It is proposed that the symbols " $\mathrm{V}_{\mathrm{L}}$ " and " $\mathrm{C}_{\mathrm{L}}$ " be generic terms for the variable and the constant regions of light chains and that " $\mathrm{V}_{\mathrm{H}}$ " and " $\mathrm{C}_{\mathrm{H}}$ " be generic terms for the corresponding regions of heavy chains. If it is desired to specify a particular class or subclass of heavy chain, the symbol " $\mathrm{H}$ " could be replaced by the symbol of the chain. For example, the $\mathrm{C}_{\mathrm{H}}$ region of a heavy chain of a molecule of the IgG1 subclass would be designated " $\mathrm{C}_{\gamma_{1}}$ region ". Similarly, if it is desired to specify a particular type of light chain, the symbol " $\mathrm{L}$ " could

* This memorandum was drafted by the signatories (see page 977) following discussions held during a WHO meeting on the nomenclature of immunoglobulins that took place on 9-11 June 1969 in Prague. A French version will be published in a later issue.

${ }^{1}$ Bull. Wld Hlth Org., 1964, 30, 447; 1965, 33, 721; 1966, 35,$953 ; 1968,38,151$. be replaced by the symbol for the chain: for example, " $\mathrm{V}_{\kappa}$ region ", $\mathrm{C}_{\lambda}$ region." 2

The exact length of these regions cannot be specified. In human light chains the $V_{L}$ and $C_{L}$ regions have about the same number of amino acid residues. For example, in the $\kappa$ (kappa) chains so far studied the $V L$ regions consist of 107 to 113 residues beginning at the amino terminus and the $C_{L}$ regions consist of the remaining 107 residues. Heavy chains have been less extensively studied than have light chains. For $\gamma$ (gamma) chains the available data on complete sequences of human heavy chains show that the $\mathrm{V}_{\mathrm{H}}$ region is of approximately the same length as the $V_{L}$ region of the same molecule and that the $\mathrm{C}_{\mathrm{H}}$ region consists of 3 linearly arranged adjacent regions which show homologies with $\mathrm{C}_{L}$ and with each other. Less extensive data on other human gamma chains and on rabbit gamma chains suggest that this will be a general finding in chains of the gamma class. It is therefore proposed that such regions in $\gamma 1$ heavy chains, for example, be named " homology region $\mathrm{C}_{\gamma_{1}} 1$ ", " homology region $\mathrm{C}_{\gamma_{1}} 2$ ", " homology region $\mathrm{C}_{\gamma_{1}} 3$ ", and so on, beginning with the homology region which is closest to the amino terminus of the chain. If similar homology regions are found in other classes, the appropriate chain symbol would be employed, e.g., " homology region $\mathrm{C}_{\alpha} 1$ ", " homology region $\mathrm{C}_{\mu} 1$ ", etc.

\section{Nomenclature of half-cystinyl residues}

It is suggested that half-cystinyl residues be designated by Roman numerals, the first residue being that which is closest to the amino terminus. An Arabic numeral (to be placed as a subscript) corresponds to the number of the amino acid residue in the chain being described. This will satisfactorily permit the representation of intrachain and interchain disulfide bonds as well as of free sulfhydryl groups. Intrachain bonds can be designated, for example, " disulfide bond $\kappa\left(\mathrm{I}_{23}-\mathrm{II}_{88}\right)$ ". Interchain bonds can be designated as follows: "disulfide bond

${ }^{2}$ The symbol " $L$ " has been suggested previously for the L type of immunoglobulins (Bull. Wld Hlth Org., 1964, 30, 447). The usage of the subscript " $L$ ", as in " $V_{L}$ " and " $C_{L}$ " is distinct: subscript " $L$ " specifies light chains irrespective of type. 
$\kappa \mathrm{V}_{214}-\gamma \mathrm{IV}_{200}$ " and " disulfide bond $\gamma 1 \mathrm{VI}_{226}-\gamma 1 \mathrm{VI}_{226}$ ". In all matters of chemical terminology the rules of IUPAC-IUB ${ }^{1}$ should be observed.

\section{Definition of groups and subgroups}

All variable regions associated with a light chain of given type are defined as a "group". Subdivisions may be distinguished within a group. These subdivisions are called "subgroups" and are designated by Roman numerals. In human $\kappa$-chain groups at least 3 discrete sets of sequences have been recognized. These are now called "subgroup $\mathrm{V}_{\boldsymbol{\kappa} \mathrm{I}}$ ", "subgroup $\mathrm{V}_{\boldsymbol{\kappa} \mathrm{II}}$ " and "subgroup $\mathrm{V}_{\boldsymbol{\kappa} \mathrm{III}}$ ". Similarly, in human $\lambda$ (lambda) chains at least 5 sets of sequences have now been recognized: these are called "subgroup V $\lambda_{\lambda I}$ ", etc. The correspondence between the present usage and the proposed usage is shown in the accompanying table. The subgroups

LIGHT CHAIN SUBGROUPS

\begin{tabular}{|c|c|c|c|c|}
\hline $\begin{array}{l}\text { Light } \\
\text { chain } a\end{array}$ & \multicolumn{3}{|c|}{ Present usage } & $\begin{array}{c}\text { Proposed } \\
\text { usage }\end{array}$ \\
\hline$\kappa$ chains & $\begin{array}{l}\mathrm{S}_{\kappa \mathrm{I}}, \\
\mathrm{S}_{\kappa \mathrm{II}}{ }^{b} \\
\mathrm{~S}_{\kappa \mathrm{II}}{ }^{b}\end{array}$ & $\begin{array}{l}\text { Tra, } \\
\text { Smi, } \\
\text { Smi, }\end{array}$ & $\begin{array}{l}\text { Basic group I } \\
\text { Basic group III } \\
\text { Basic group II }\end{array}$ & $\begin{array}{l}\mathrm{V}_{\kappa \mathrm{I}} \\
\mathrm{V}_{\kappa \mathrm{II}} \\
\mathrm{V}_{\kappa \mathrm{III}}\end{array}$ \\
\hline$\lambda$ chains & $\begin{array}{l}\text { I, } \\
\text { II, } \\
\text { IV, } \\
\text { II, } \\
\text { III, }\end{array}$ & $\begin{array}{l}\mathbf{S}_{\lambda I I} \\
\mathbf{s}_{\lambda I} \\
\text { other } \\
\mathbf{s}_{\lambda I I I} \\
\text { other }\end{array}$ & & $\begin{array}{l}v_{\lambda I} \\
v_{\lambda I I} \\
v_{\lambda I I I} \\
v_{\lambda I V} \\
v_{\lambda V}\end{array}$ \\
\hline
\end{tabular}

$a$ References:

$\kappa$ chain:

Hood, L., Gray, W. R., Sanders, B. G. \& Dreyer, W. J. (1967) Cold Spr. Harb. Symp. quant. Biol., 32, 133.

Niall, H. \& Edman, P. (1967) Nature'(Lond.), 216, 263.

Milstein, C. (1967) Nature (Lond.), 216, 330.

$\lambda$ chain:

Langer, B., Steinmetz-Kayne, M. \& Hilschmann, N. (1968) Hoppe-Seylers Z. physiol Chem., 349, 945.

Hood, L. \& Ein, D. (1968) Nature (Lond.), 220, 764.

$b$ These subgroups were not further separated at the time of publication.

have been designated I, II and III, etc. in order of their frequency of occurrence in the chains which have so far been studied. This follows the nomenclature of subclasses of heavy chains of IgG, which are also numbered in order of frequency of occur-

${ }^{1}$ See, for instance, IUPAC-IUB Commission on Biochemical Nomenclature (1966) J. biol. Chem., 241, 527, 2491. rence. ${ }^{2}$ Prototype sequences of 20 residues of the subgroups beginning at the amino terminus are given in the Annex to this paper.

\section{Definition of classes and subclasses and types and subtypes}

$C_{H}$ and $C_{L}$ regions show heterogeneity. This is the basis of the recognition of classes of heavy chains and types of light chains. Subdivisions of classes have previously been designated subclasses. It is proposed that similar subdivisions of types be designated "subtypes" and that the principles for their nomenclature should be the same as those for subclasses. The terms " classes" and " subclasses", " types" and " subtypes" specifically exclude differences arising owing to allelism.

\section{Formulae for immunoglobulin molecules}

The over-all structure of immunoglobulins may be represented by formulae. Thus, an IgG1 molecule with $\kappa$ light chains of subgroup I could be written

$$
\left[\left(\mathrm{V}_{\kappa \mathrm{I}} \mathrm{C}_{\kappa}\right)\left(\mathrm{V}_{\gamma} \mathrm{C}_{\gamma \mathrm{I}}\right)\right]_{2}
$$

If it is desired to include homology regions, this could be expanded to

$$
\left[\left(\mathrm{V}_{\kappa \mathrm{I}} \mathrm{C}_{\kappa}\right)\left(\mathrm{V}_{\gamma} \mathrm{C}_{\gamma_{1}} 1 \mathrm{C}_{\gamma_{1}} 2 \mathrm{C}_{\gamma_{1}} 3\right)\right]_{2}
$$

Presence inside the square brackets indicates association of light and heavy chains, the formula for each of which is in parentheses. The subscript 2 outside the brackets indicates that the association of 2 such units forms the molecule. An IgM molecule with $\kappa$ light chains may be represented, by use of the brace, as

$$
\left\{\left[\left(V_{\kappa} C_{\kappa}\right)\left(V_{\mu} C_{\mu}\right)\right]_{2} ; \bar{s}\right.
$$

Formulae could be especially useful in representing certain $\gamma \mathrm{A}$ immunoglobulins in which the 2 light chains are linked as $\left(\mathrm{V}_{\kappa} \mathrm{C}_{\kappa}\right)_{2}$ and the heavy chains as $\left(\mathrm{V}_{\alpha} \mathrm{C}_{\alpha}\right)_{2}$ to give

$$
\left[\left(\mathrm{V}_{\kappa} \mathrm{C}_{\kappa}\right)_{2}\left(\mathrm{~V}_{\alpha} \mathrm{C}_{a}\right)_{2}\right]
$$

\section{Immunoglobulins of secretions}

The IgA in the external secretions of man and several other species has a molecular structure characterized by the presence of an additional component which is lacking in IgA derived from serum. This additional component is sometimes encountered not bound to IgA. It is suggested that it be designated "secretory component" or " $S$

'Bull. Wld Hlth Org., 1966, 35, 953. 
component" and that other terms such as "transport piece" should not be used. The term "secretory" in the definition is not meant to imply any function but rather to indicate the characteristic association with secretions of IgA possessing this additional component.

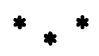

R. Asofski, National Institute of Allergy and Infectious Diseases, Bethesda, Md., USA

R. A. Binaghi, Laboratoire de Médecine expérimentale, Collège de France, Paris, France

G. M. Edelman, The Rockefeller University, New York, N.Y., USA

H. C. Goodman, Immunology, World Health Organization, Geneva, Switzerland
J. F. Heremans, Cliniques universitaires St Pierre, Université catholique de Louvain, Louvain, Belgium

L. Hood, National Cancer Institute, Bethesda, Md., USA

E. A. KabAt, Columbia-Presbyterian Medical Center, New York, N.Y., USA

J. ReJNeK, Department of Immunology, Institute of Microbiology, Prague, Czechoslovakia

D. S. Rowe, Director, WHO International Reference Centre for Immunoglobulins, Lausanne, Switzerland

P. A. Small, Jr, Department of Microbiology, College of Medicine, University of Florida, Gainsville, Fla., USA

Z. TRNKA, Immunology, World Health Organization, Geneva, Switzerland 
TERMINOLOGY

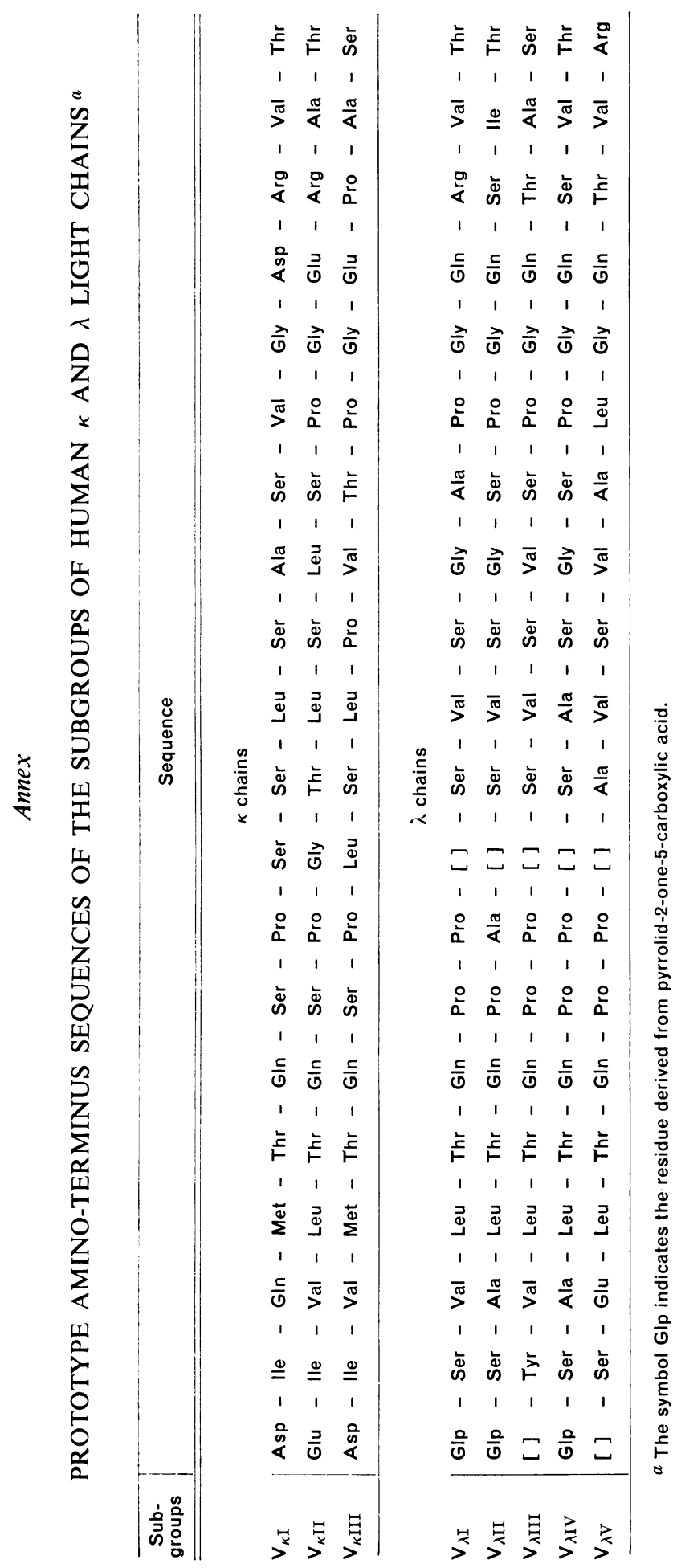




\section{Transliteration}

\section{from Cyrillic characters}

The "International System for the Transliteration of Cyrillic Characters", set out in Recommendation ISO/R9-1954 (E) of the International Organization for Standardization, is normally used in the Bulletin of the World Health Organization for personal names, titles of publications, etc. However, papers accepted for publication may contain names transliterated differently, and if the original Cyrillic spelling is not recognizable inconsistencies may occur.

For convenience the transliteration from Russian according to ISO/R9 is given below:

\section{Translittération}

\section{des Caractères cyrilliques}

Le "Système international pour la translittération des caractères cyrilliques " présenté dans la Recommandation ISO/R9-1954 (F) de l'Organisation internationale de Normalisation est généralement utilisé dans le Bulletin de l'Organisation mondiale de la Santé pour les noms de personnes, les titres de publications, etc. Cependant des articles acceptés pour publication peuvent contenir des noms translittérés différemment et si l'orthographe cyrillique originale n'est pas reconnaissable un manque d'uniformité peut s'ensuivre.

A toutes fins utiles, la translittération du russe selon la recommandation ISO/R9 est indiquée ci-après:

\begin{tabular}{|c|c|c|c|c|c|c|c|}
\hline \multirow{2}{*}{$\begin{array}{c}\begin{array}{c}\text { Cyrillic } \\
\text { character } \\
\text { Caractère } \\
\text { cyrillique }\end{array} \\
\mathrm{A}, \mathrm{a} \\
\end{array}$} & \multirow{2}{*}{ 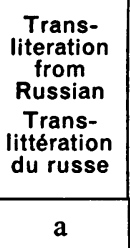 } & \multicolumn{2}{|c|}{$\begin{array}{l}\text { Examples and remarks } \\
\text { Exemples et observations }\end{array}$} & \multirow{2}{*}{$\begin{array}{l}\begin{array}{c}\text { Cyrillic } \\
\text { character } \\
\text { Caractere } \\
\text { cyrillique }\end{array} \\
\mathrm{y}, \mathrm{y}\end{array}$} & \multirow{2}{*}{ 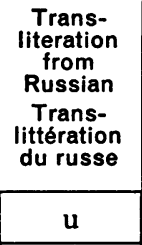 } & \multicolumn{2}{|c|}{$\begin{array}{l}\text { Examples and remarks } \\
\text { Exemples et observations }\end{array}$} \\
\hline & & Адрес & $=$ Adres & & & Утро $=$ Utro & \\
\hline Б, $б$ & b & Баба & $=\mathrm{Baba}$ & $\Phi, \phi$ & f & Физика & $=$ Fizika \\
\hline $\mathrm{B}, \mathrm{B}$ & $\mathbf{v}$ & Вы & $=\mathrm{Vy}$ & $\mathrm{X}, \mathrm{x}$ & h & Химический & $=$ Himičeskij \\
\hline \multirow{2}{*}{$\Gamma, r$} & \multirow[t]{2}{*}{ g } & \multirow{2}{*}{$\begin{array}{l}\text { Глава } \\
\text { Голова }\end{array}$} & \multirow{2}{*}{$\begin{array}{l}=\text { Glava } \\
=\text { Golova }\end{array}$} & Ц, ц & c & Центральный & $=$ Central'nyj \\
\hline & & & & 4,4 & $\check{\mathbf{c}}$ & Часы & $=$ Časy \\
\hline Д, д & d & Да & $=\mathrm{Da}$ & Ш, ш & $\check{s}$ & Школа & $=$ Skola \\
\hline$E, e(\ddot{e})^{1}$ & e (ë) & Ещё & $=$ Eščë & щ, щ & šč & Щека & $=$ Sčeka \\
\hline ж, ж & $\check{\mathbf{z}}$ & Журнал & $=\check{Z}$ urnal & \multirow{8}{*}{$\begin{array}{c}\text { (medial, } \\
\text { médial) } \\
\mathbf{b}, \mathbf{b}\end{array}$} & \multirow{8}{*}{$\begin{array}{l}\text { trans- } \\
\text { literated. } \\
\text { Non trans- } \\
\text { littéré.) }\end{array}$} & \multirow{8}{*}{\multicolumn{2}{|c|}{$\begin{array}{l}\text { In modern Russian, where ' } \\
\text { sometimes replaces medial } \mathrm{b} \text {, } \\
\text { transliteration is still ". } \\
\text { En russe moderne, où le ' rem- } \\
\text { place quelquefois le } \mathrm{b} \text { médial, la } \\
\text { translittération reste ". }\end{array}$}} \\
\hline 3,3 & $\mathbf{z}$ & Звезда & $=$ Zvezda & & & & \\
\hline И, и & $\mathrm{i}$ & Или & $=$ Ili & & & & \\
\hline И, й & j & -ый, -ий, -ой & $=-\mathrm{yj},-\mathrm{ij},-\mathrm{oj}$ & & & & \\
\hline $\mathrm{K}, \mathrm{K}$ & k & Как & $=\mathrm{Kak}$ & & & & \\
\hline Л, л & 1 & Любить & $=$ Ljubit' $^{\prime}$ & & & & \\
\hline$M, M$ & $\mathrm{~m}$ & Муж & $=\mathrm{Muž}$ & & & & \\
\hline $\mathrm{H}, \mathbf{H}$ & $\mathrm{n}$ & Нижний & $=$ Nižnij & & & & \\
\hline 0,0 & $\mathbf{o}$ & Общество & $=$ Obščestvo & Ы, ы & $y$ & Был & $=\mathrm{Byl}$ \\
\hline$\Pi, \Pi$ & $\mathrm{p}$ & Первый & $=$ Pervyj & $\mathbf{b}, \mathbf{b}$ & or' 'ou' & Маленький & $=$ Malen'kij \\
\hline$P, p$ & $\mathbf{r}$ & Рыба & $=$ Ryba & Э, э & $\stackrel{\circ}{\mathbf{e}}$ & Это & $=$ Ẽto \\
\hline $\mathrm{C}, \mathrm{c}$ & $\mathbf{s}$ & Сестра & $=$ Sestra & Ю, ю & $\mathrm{ju}$ & Южный & $=$ Južnyj \\
\hline $\mathrm{T}, \mathrm{T}$ & $\mathbf{t}$ & Товарищ. & $=$ Tovarišč & Я, Я & ja & Яйцо & $=$ Jajco \\
\hline
\end{tabular}

' Cyrillic ë to be transliterated by ë only when the diacritical appears in the original. Le ë cyrillique ne doit être translittéré par ë que lorsque la diacritique apparait dans l'original. 